\title{
Relevansi Pemeriksaan Calon Tersangka sebelum Penetapan Tersangka
}

\author{
Erdianto Effendi \\ Fakultas Hukum Universitas Riau \\ erdianto.effendi@gmail.com
}

\begin{abstract}
In Indonesian criminal procedure law, there is no requirement for an investigator to first conduct an examination of a potential suspect until the determination as a suspect. The determination of a suspect is deemed sufficiently reasonable if it is based on examination of evidence, ranging from witness testimony, expert testimony, document and other evidence. After the Decision of the Constitutional Court Number 21/PUU$\mathrm{XII} / 2014$, there were differences in interpretation and debate regarding the examination of the potential suspect, because this examination was mentioned in the consideration of the decision as a necessity but not part of the verdict. In this article, it is revealed that the designation of a person as a suspect is part of forced efforts and is almost equivalent to the designation of a person as a convicted person due to the similarities in the various restrictions and deprivation of rights that can be applied as a result of the two determinations, for example in detention. The shift in the meaning of the determination of a suspect as part of this forced effort encourages that citizens' rights be protected not only when a person is a suspect, but also before becoming a suspect. Thus, the rights inherent in a suspects also needs to be given to those who will be designated as suspects, also called as potential suspects.
\end{abstract}

Keywords: suspect; potential suspect; investigation; human rights. 


\section{Abstrak}

Dalam hukum acara pidana Indonesia, tidak ada keharusan bagi penyidik untuk terlebih dahulu melakukan pemeriksaan calon tersangka sehingga sampai pada penetapannya sebagai tersangka. Penetapan tersangka dipandang telah cukup beralasan apabila didasarkan pada pemeriksaan alat bukti, mulai dari keterangan saksi, keterangan ahli, surat, dan bukti lainnya. Pasca Putusan Mahkamah Konstitusi Nomor 21/PUU-XII/2014, terjadi perbedaan penafsiran dan perdebatan tentang pemeriksaan calon tersangka ini, disebabkan pemeriksaan ini disebut dalam bagian pertimbangan putusan sebagai suatu keharusan namun tidak menjadi bagian amar putusan. Dalam artikel ini ditunjukkan, penetapan seseorang sebagai tersangka merupakan bagian dari upaya paksa dan bahkan hampir setara dengan penetapan seseorang sebagai terpidana, disebabkan kesamaan berbagai pembatasan dan perampasan hak yang dapat diterapkan akibat dari dua penetapan tersebut, misalnya dalam penahanan. Perubahan pemaknaan penetapan tersangka sebagai bagian dari upaya paksa ini mendorong agar hak-hak warga negara telah harus dilindungi tidak saja ketika seseorang sudah berstatus tersangka, tetapi juga pada saat sebelum menjadi tersangka. Dengan demikian, hak-hak yang melekat dalam diri tersangka juga perlu diberikan kepada mereka yang akan ditetapkan sebagai tersangka, atau disebut calon tersangka.

Kata kunci: calon tersangka; tersangka; pemeriksaan; hak asasi manusia.

\section{A. Pendahuluan}

Artikel ini membahas relevansi pemeriksaan calon tersangka sebelum ditetapkan sebagai tersangka. Dalam hukum acara pidana, sebagaimana ketentuan Kitab Undang-undang Hukum Acara Pidana (KUHAP), sesungguhnya tidak ada keharusan bagi penyidik untuk terlebih dahulu melakukan pemeriksaan terhadap calon tersangka sehingga sampai pada penetapannya sebagai tersangka. Penetapan tersangka cukup dilakukan dengan pemeriksaan alat bukti, mulai dari keterangan saksi, keterangan ahli, surat, dan bukti lainnya. Namun demikian, pasca Putusan Mahkamah Konstitusi (MK) Nomor 21/ PUU-XII / 2014, terdapatperbedaan penafsiran dan perdebatan tentang perlu atau tidaknya pemeriksaan calon tersangka. Hal ini disebabkan 
pemeriksaan calon tersangka disebut dalam pertimbangan Putusan MK sebagai suatu keharusan, namun tidak ditemukan dalam amar putusan. Dalam artikel ini ingin ditegaskan, pemeriksaan calon tersangka sesungguhnya penting dan relevan dalam penegakan hukum, dan demi kepastian hukum maka pemeriksaan calon tersangka ini ke depannya perlu didorong sebagai suatu keharusan.

Sebagaimana diketahui, KUHAP disusun dengan spirit untuk menghormatihakasasi manusia. Selamaini, sebelumlahirnya KUHAP, penegakan hukum dilakukan dengan pendekatan tangkap saja dulu, kemudian peras pengakuannya, dan semua cara adalah halal untuk memperoleh pengakuan. ${ }^{1}$ KUHAP mengangkat dan menempatkan tersangka atau terdakwa dalam kedudukan "berderajat", sebagai makhluk Tuhan yang memiliki harkat derajat kemanusiaan yang utuh. Tersangka atau terdakwa ditempatkan dalam posisi his entity and dignity as human being, yang harus diperlakukan sesuai nilainilai luhur kemanusiaan. M. Yahya Harahap mencatat setidaknya ada empat hak dasar tersangka yang tidak boleh ditelanjangi oleh penegak hukum, antara lain persamaan hak dan kedudukan serta kewajiban di hadapan hukum; harus dianggap tidak bersalah atau praduga tak bersalah; penangkapan atau penahanan didasarkan atas bukti permulaan yang cukup; serta hak menyiapkan pembelaan diri. $^{2}$

Berkembangnya persoalan hukum di masyarakat dan praktik penegakannya telah pula menimbulkan pertanyaan bahkan kritik terhadap KUHAP. Komunitas hukum bahkan sampai pada kesimpulan, meskipun dirancang dengan sangat baik pada masanya, KUHAP untuk saat sekarang mengandung banyak kelemahan sehingga harus direvisi. Proses revisi KUHAP menuju yang baru masih terus berjalan, akan tetapi kebutuhan masyarakat akan keadilan tidaklah bisa ditunda. Dalam konteks ini, putusan Mahkamah Konstitusi terkait KUHAP menjadi semacam alternatif pencarian keadilan yang bersifat merevisi KUHAP sebatas permohonan yang diajukan.

1 M. Yahya Harahap, Pembahasan Permasalahan dan Penerapan KUHAP: Penyidikan dan Penuntutan (Jakarta: Sinar Grafika, 2002), hlm. 3.

2 Harahap, Pembahasan Permasalahan dan Penerapan KUHAP, hlm. 3. 
Putusan Mahkamah Konstitusi Nomor 21 / PUU-XII/ 2014 pada intinya memungkinkan dapat diperiksanya penetapan tersangka sebagai objek pra-peradilan, meskipun Peraturan Mahkamah Agung (Perma) Nomor 4 Tahun 2016 membatasi pemeriksaan pra-peradilan terhadap permohonan tentang tidak sahnya penetapan tersangka hanya menilai aspek formil, yaitu apakah ada paling sedikit dua alat bukti yang sah, dan tidak memasuki materi perkara. Pra-peradilan merupakan sebuah lembaga yang lahir atas dasar pemikiran untuk mengadakan suatu tindakan pengawasan terhadap aparat penegak hukum agar dalam melaksanankan kewenanganya tidak terjadi penyalahgunaan. Pra-peradilan dalam hal ini menjadi pengawasan silang antar sesama aparat penegak hukum, di samping pengawasan internal yang terdapat dalam instansi perangkat aparat hukum itu sendiri. ${ }^{3}$

Putusan Mahkamah Konstitusi ini terbangun atas pola penalaran dari pengakuan asas due process of law sebagai konsekuensi dari negara hukum yang patut diterapkan dalam sistem peradilan pidana. Mahkamah Konstitusi juga masuk ke sisi humanisme dengan fokus kajian antroposentrisme yang mengadopsi asas acussatoir dalam KUHAP. Dengan demikian, Mahkamah Konstitusi beranjak dari titik pandang tersangka sebagai manusia seutuhnya, dan bukan hanya sekadar objek dalam proses atau prosedur penetapannya sebagai tersangka, hal mana KUHAP tidak memuat norma hukum yang mengatur cara bagaimana menetapkan seseorang sebagai tersangka. ${ }^{4}$ Dari Putusan ini, Rocky Marbun mengidentifikasi terdapat tujuh persoalan yang dapat dipermasalahkan dan sekaligus merupakan pedoman penyidikan. Satu dari tujuh poin itu adalah adanya pemeriksaan calon tersangka terlebih dahulu dalam perkara dugaan tindak pidana terhadap dirinya sendiri, kecuali dikaitkan dengan

3 Ardli Nuur Ihsani, "Urgensi Perluasan Objek Praperadilan dalam Tindak Pidana Korupsi Ditinjau dari Perspektif Perlindungan Hak Asasi Tersangka”, Legal Standing: Jurnal Ilmu Hukum, 1, 2 (2017), hlm. 70.

4 Rocky Marbun, Telaah Kritis Filosofis Praktik Peradilan Pidana: Membongkar Oposisi Biner antara Kekuasaan dan Kewenangan (Yogyakarta: Arti Bumi Intaran, 2019), hlm. 346. 
penyertaan (delneming). ${ }^{5}$

Putusan Mahkamah Konstitusi tentang pra-peradilan ini dalam perkembangannya telah mendapat legitimasi dan pengakuan secara yuridis, yang ditunjukkan dengan telah banyaknya Putusan Praperadilan yang mengabulkan permohonan pengujian penetapan tersangka. Dalam buku Kompilasi da Re-Publikasi Putusan-putusan Pra Peradilan terhadap Penetapan Tersangka yang diterbitkan Mahkamah Agung Republik Indonesia pada 2016, terdapat delapan putusan pra-peradilan, yang pada umumnya menerima permohonan yang diajukan. Dari delapan putusan tersebut, terdapat beberapa prinsip yang idealnya dapat diikuti oleh hakim lain sebagai yurisprudensi, antara lain ialah penetapan tersangka merupakan bagian dari upaya paksa, karena dengan ditetapkannya seseorang sebagai tersangka maka akan terkurangi hak asasinya.

Dari delapan putusan tersebut, serta berbagai putusan praperadilan yang menguji penetapan tersangka, yang paling banyak dikabulkan adalah terkait dengan ketiadaan alat bukti yang cukup sebagai dasar penetapan tersangka. Terkait dengan ketiadaan alat bukti tersebut, menurut Putusan Mahkamah Konstitusi harus sejalan pula dengan kepastian adanya pemeriksaan calon tersangka sebelum penetapan seseorang menjadi tersangka. Penetapan tersangka yang didasarkan atas dua alat bukti, harus didahului juga dengan pemeriksaan calon tersangka.

Dalam artikel ini, pembahasan relevansi pemeriksaan calon tersangka sebelum penetapan tersangka akan dimulai dengan pembahasan tentang pemeriksaan calon tersangka dan penetapan tersangka. Uraian ini dimaksudkan untuk memperjelas keterkaitan antara pemeriksaan calon tersangka dan penetapan tersangka. Bagian berikutnya membahas tentang relevansi pemeriksaan calon tersangka sebelum penetapan tersangka. Bahasan ini penting karena dimaksudkan untuk menjelaskan mengapa pemeriksaan calon tersangka diperlukan. Artikel diakhiri dengan penyampaian kesimpulan.

5 Marbun, Telaah Kritis Filosofis Praktik Peradilan, hlm. 351. 


\section{B. Pemeriksaan Calon Tersangka dan Penetapan Tersangka}

Pada dasarnya, seperti dalam hukum pidana materiel, proses dan prosedur yang dibangun dalam hukum pidana formil (Hukum Acara Pidana) juga dilandasi oleh asas legalitas (principle of legality). Dalam Pasal 3 KUHAP ditentukan bahwa "peradilan dilakukan menurut cara yang diatur dalam undang-undang ini”. Ketentuan ini merupakan penegasan asas legalitas dalam hukum acara pidana, seperti juga hal yang serupa ditegaskan dalam Pasal 1 ayat (1) Kitab UndangUndang Hukum Pidana (KUHP), sebagai perumusan asas legalitas dalam hukum pidana subtantif. Hukum acara pidana karenanya juga memiliki sifat lex scripta, lex stricta, lex certa, sebagai komponen dasar dari asas legalitas. ${ }^{6}$

Hal ini membawa konsekuensi bahwa pengaturan yang sifatnya hukum acara pidana tidak dapat didelegasikan kepada peraturan perundang-undangan di bawah undang-undang. Dengan kata lain, KUHAP seharusnya memuat ketentuan yang operasional sedemikian rupa sehingga telah dapat dijalankan tanpa diatur lebih lanjut dalam peraturan perundangan di bawah undang-undang. Namun demikian, sejumlah instrumen hukum acara pidana ternyata telah diatur dalam peraturan perundang-undangan di bawah undang-undang. ${ }^{7}$

Dalam hukum acara pidana, proses penetapan tersangka merupakan bagian akhir dalam proses penyidikan, yaitu suatu tindakan untuk mencari dan mengumpulkan bukti terhadap suatu perkara dan menemukan seseorang yang karena keadaan dan perbuatannya patut diduga sebagai pelaku tindak pidana. Pasal 183 KUHAP mengatur, hakim tidak boleh menjatuhkan pidana kepada seseorang kecuali apabila dengan sekurang-kurangnya dua alat bukti yang sah diperoleh keyakinan bahwa tindak pidana benar-benar terjadi dan terdakwa bersalah melakukannya. Para ahli dan berbagai putusan pengadilan mendefinisikan alat bukti yang sah sebagai alat bukti yang didapatkan dengan cara menurut undang-undang. Alat

6 Pendapat Chairul Huda dalam Putusan Mahkamah Konstititusi Nomor 21 / PUU-XII / 2014, hlm. 25.

7 Putusan Mahkamah Konstititusi Nomor 21/PUU-XII/2014, hlm. 25. 
bukti yang diperoleh dengan cara yang tidak berdasar undang-undang harus dikesampingkan.

Untuk sampai pada keyakinan bahwa seseorang dapat ditetapkan sebagai tersangka, penyidik harus melakukan pemeriksaan terhadap alat bukti, mulai dari keterangan saksi, keterangan ahli, surat, dan bukti lainnya. Untuk disebut layak sebagai alat bukti, keterangan saksi tersebut minimal dua orang saksi, dan harus diperiksa pula kualitas kesaksian itu, bukan sekadar ada saksi. Bagaimana perilaku dan kesusilaan saksi, hubungan saksi dengan calon tersangka, sehingga berpengaruh pada keterangannya. Begitu pula keterangan seorang ahli, harus dilihat juga kualitas keterangan tersebut, bukan sekadar ada keterangan ahli.

Dengan mendalilkan pada Pasal 183 KUHAP, secara normatif tidak ditemukan adanya pemeriksaan calon tersangka. Istilah calon tersangka pun tidak ditemukan dalam KUHAP atau perundangundangan lainnya. Begitu sudah ada minimal dua alat bukti atau bahkan alat bukti permulaan yang cukup, sebelum kemudian ditafsirkan secara limitatif oleh Mahkamah Konstitusi, seseorang telah dapat ditetapkan sebagai tersangka. Bahkan, laporan polisi pun telah dikualifikasi sebagai alat bukti, sehingga dengan hanya berbekal satu laporan polisi ditambah keterangan dua orang saksi, seseorang yang dilaporkan telah dapat ditetapkan sebagai tersangka.

Uraian demikian itu menunjukkan begitu mudah dan sederhananya proses penetapan tersangka. Padahal, seseorang yang telah ditetapkan sebagai tersangka sesungguhnya telah diambil sebagian dari hak asasinya. Jamak terjadi dalam praktik penegakan hukum, tersangka dalam tindak pidana yang diancam dengan pidana lebih dari lima tahun akan dikenakan penahanan oleh penyidik. Penahanan yang semestinya dipahami sebagai kewenangan yang hanya digunakan jika sangat diperlukan, dalam praktik dipahami sebagai hak untuk menahan orang. Tersangka, bahkan juga keluarganya, masih harus menghadapi sanksi sosial, semisal pengucilan dan stigmatisasi. Padahal, jarak antara penetapan seseorang sebagai tersangka dan putusan dari pengadilan yang berkekuatan hukum tetap yang menetapkannya bersalah, sesungguhnya masih jauh. Bahkan 
tidak sedikit darinya yang pada akhirnya dibebaskan oleh putusan pengadilan.

Secara normatif memang benar bahwa penetapan tersangka cukup dengan didasarkan pada dua alat bukti. Keterangan tersangka dapat diabaikan, karena tersangka atau terdakwa memiliki hak untuk ingkar. Begitu telah ada dua alat bukti, sudah cukup alasan untuk menetapkan seseorang sebagai tersangka. Tidak ada kewajiban memeriksacalon tersangka, sebagaisaksisekalipun. Bahkantidakwajib pula bagi penyidik untuk memeriksa saksi atau ahli yang meringankan yang diajukan oleh pihak tersangka, karena mendatangkan saksi dan ahli hanyalah hak tersangka setelah ditetapkan sebagai tersangka, bukan sebelumnya. Akses untuk didampingi penasehat hukum pun tidak mudah sebagaimana mestinya.

Meskipun seorang tersangka dapat dikenakan berbagai pembatasan hak asasi yang dimilikinya, tidak berarti ia dapat diperlakukan sewenang-wenang sehingga mengesankan seluruh haknya sebagai warga negara telah hilang sama sekali. Pembatasanpembatasan hak-hak warga negara dalam suatu negara yang berdasar atas hukum, menurut Mardjono hanya diperbolehkan apabila dibenarkan oleh hukum itu sendiri melalui suatu proses peradilan pidana yang adil (due process of law) sebagai lawan dari arbitrary process atau proses peradilan yang sewenang-wenang. ${ }^{8}$

Secara lebih sederhana, Mien Rukmini ${ }^{9}$ menyatakan bahwa unsur minimal dari proses hukum yang adil (due process of law) adalah mendengarkan keterangan tersangka dan terdakwa; penasihat hukum dalam pembelaan; pengadilan yang adil dan tidak memihak. Hal ini sejalan dengan unsur asas praduga tidak bersalah, yaitu perlindungan terhadap tindakan sewenang-wenang dari pejabat negara; pengadilan sebagai yang berhak menentukan salah tidaknya terdakwa; sidang pengadilan harus terbuka, tidak boleh bersifat rahasia; serta tersangka

8 Pendapat Arief Setiawan dalam Putusan Mahkamah Konstititusi Nomor 21 / PUU-XII / 2014, hlm. 45.

9 Mien Rukmini, Perlindungan HAM melalui Asas Praduga tak Bersalah dan Asas Persamaan Kedudukan dalam Hukum pada Sistem Peradilan Pidana Indonesia (Bandung: Alumni), 2007, hlm. 31. 
dan terdakwa harus diberikan jaminan-jaminan untuk dapat membela diri sepenuh-penuhnya. ${ }^{10}$

Kesetaraan hak-hak tersangka dengan polisi dan jaksa menunjukkan bahwa KUHAP mengandung prinsip acusatoir di mana tersangka diperlakukan sebagai subjek bukan objek. Dalam putusan sebagaimana yang dibahas dalam artikel ini, Mahkamah Konstitusi telah memeprtimbangkan bahwa "menyertakan pemeriksaan calon tersangka di samping minimum dua alat bukti tersebut di atas, adalah untuk tujuan transparansi dan perlindungan hak asasi seseorang agar sebelum seseorang ditetapkan sebagai tersangka sudah dapat memberikan keterangan yang seimbang dengan minimum dua alat bukti yang telah ditemukan oleh penyidik."

Hak untuk memberikan tafsir terhadap Konstitusi maupun produk hukum lainnya memang bukanlah kewenangan monopoli dari lembaga peradilan. Pemerintah dan DPR juga memiliki kewenangan tersebut dalam konteks kebijakan hukum terbuka (open legal policy) maupun diskresi. Namun demikian, agar penafsiran terhadap teks Konstitusi memiliki kekuatan hukum yang dapat diakui seluruh elemen negara, maka peradilan diberikan kewenangan untuk memberikan tafsir tersebut. Dengan demikian, penafsiran Konstitusi yang dimiliki oleh pembuat undang-undang dan lembaga peradilan adalah dua hal yang terpisah. Pemerintah dan parlemen menafsirkan peraturan perundang-undangan untuk menjalankan peraturan tersebut, sedangkan lembaga peradilan menafsirkan suatu peraturan untuk menguji keabsahan norma dalam peraturan tersebut. ${ }^{11}$

\section{Relevansi Pemeriksaan Calon Tersangka sebagai Penghormatan Hak Asasi Manusia}

KUHAP telah meletakkan landasan prinsip legalitas dan pendekatan pemeriksaan dalam semua tingkat, dengan sistem akuisatur.

10 Rukmini, Perlindungan HAM, hlm. 32.

11 Despan Heryansyah dan Harry Setya Nugraha, "Relevansi Putusan Uji Materi oleh Mahkamah Konstitusi terhadap Sistem Checks and Balances dalam Pembentukan Undang-Undang”, Undang: Jurnal Hukum, 2, 2 (2019), hlm. 367. 
KUHAP menempatkan tersangka dan terdakwa dalam setiap tingkat pemeriksaan sebagai manusia yang memiliki hak asasi dan harkat martabat harga diri. ${ }^{12}$ Menurut Andi Hamzah, asas legalitas dalam KUHAP adalah tentang cara mengadili dalam proses pidana yang harus dilaksanakan berdasarkan Undang-undang, bukan berdasarkan peraturan di bawah Undang-undang. ${ }^{13}$ KUHAP lebih menekankan dalam setiap proses peradilan pidana memperlihatkan ciri humanis, yang merupakan cara baru yang dianut di Indonesia. Dalam KUHAP, semua tersangka dan terdakwa mendapatkan perlakuan yang sama, yang berbeda dengan pada waktu Indonesia menganut sistem dalam HIR. ${ }^{14}$

Terhadap sedemikian lengkapnya jaminan atas hak-hak tersangka, patut diajukan pertanyaan, mengapa negara harus sedemikian rupa melindungi hak-hak asasi tersangka padahal mereka merupakan "orang jahat" yang melakukan tindak pidana yang karenanya wajar jika mereka harus dihukum. Demikian pertanyaan yang sering muncul di tengah publik khususnya dari kalangan mereka yang awam tentang hukum.

Cara pandang yang selaras dengan pertanyaan itu pula yang kerap kali juga muncul di kalangan penegak hukum, sehingga seakan menjadi dasar legitimasi untuk dapat melakukan tindakan apapun terhadap tersangka. Meskipun undang-undang telah lama berubah, cara pandang klasik terhadap tersangka belum banyak berubah karena tidak mempelajari buku dan undang-undang, akan tetapi lebih banyak belajar dari kebiasaan para penegak hukum di masa HIR. Menurut Agus Rahardjo dan Angkasa, meski dibekali dengan kemampuan teknik dan taktik interogasi, polisi dalam praktiknya masih mengedepankan kekerasan dalam memperoleh keterangan atau pengakuan tersangka. ${ }^{15}$

12 Bambang Tri Bawono, “Tinjauan Yuridis Hak-Hak Tersangka dalam Pemeriksaan Pendahuluan”, Jurnal Hukum, 26, 2 (2011), hlm. 559.

13 Andi Hamzah dan RM Surachman, Pre Trial Justice Discretionary Justice dalam KUHAP Berbagai Negara (Jakarta: Sinar Grafika, 2015), hlm. 27.

14 Mien Rukmini, Aspek Hukum Pidana dan Kriminologi: Sebuah Bunga Rampai (Bandung: Alumni, 2009), hlm. 149.

15 Agus Raharjo dan Angkasa, "Perlindungan Hukum terhadap Tersangka 
Pertanyaan demikian itu perlu dijawab dengan pemahaman atas asas praduga tak bersalah. Praktik hukum menunjukkan bahwa banyak sekali tersangka yang dirampas hak-hak asasinya sebelum adanya putusan pengadilan. Berhadapan dengan kenyataan di dalam praktik tentang banyaknya hak-hak tersangka yang terampas saat berhadapan dengan kesewenang-wenangan penegak hukum, Mahkamah Konstitusi telah banyak menerima permohonan uji perundang-undangan terkait penafsiran atas KUHAP yang saat sekarang tidak sempurna, yang menjadi celah bagi penegak hukum untuk menyalahgunakan kewenangannnya yang berakibat terampasnya hak asasi tersangka. Padahal tujuan utama dari KUHAP adalah membatasikewenangan penegak hukum agar tidak menciderai rasa keadilan dan merampas hak asasi manusia secara sembrono.

Menurut Sayed Muhammad, dkk., ada dua penyebab tidak terlaksananya perlindungan hak asasi manusia dalam pemeriksaan tersangka. Pertama, faktor psikologis anggota kepolisian berkaitan dengan tugas di lapangan tidak jarang mengundang bahaya. Hal ini menyebabkan terjadinya tindakan yang melangar ketentuan perundang-undangan dan tingkat ancaman serta resiko pekerjaan sangat tinggi. Faktor kedua berkaitan dengan pemahaman terhadap beberapa peraturan perundang-undang. ${ }^{16}$

Pada negara-negara Anglo Saxon, perolehan bukti secara tidak sah berkaitan dengan dengan exclusionary rules, yaitu suatu aturan yang berlaku umum dan berisikan larangan penggunaan alat bukti yang diperoleh penyidik secara tidak sah atau melanggar undangundang. ${ }^{17} \mathrm{Hal}$ ini sesungguhnya sudah diakomodasi Pasal 183 KUHAP, yang menyatakan bahwa hakim tidak boleh menjatuhkan pidana kepada seseorang kecuali apabila dengan sekurang-kurangnya dua alat bukti yang sah diperoleh keyakinan bahwa tindak pidana benar-

dalam Penyidikan dari Kekerasan Penyidik di Kepolisian Resort Banyumas”, Mimbar Hukum, 23, 1 (2011), hlm. 87.

16 Sayed Muhammad Rafsanjani, Iskandar A. Gani, dan Mohd. Din, “Terhadap Pemeriksaan Tersangka yang Dilakukan Penyidik Kaitannya dengan Kode Etik Kepolisian Negara Republik Indonesia”, Jurnal Ilmu Hukum, 3, 3 (2001), hlm. 65.

17 Rukmini, Perlindungan HAM, hlm. 117. 
benar terjadi dan bahwa terdakwa bersalah melakukannya. Para ahli dan berbagai putusan pengadilan mendefinisikan alat bukti yang sah sebagai alat bukti yang didapatkan dengan cara menurut undangundang. Alat bukti yang diperoleh dengan cara yang tidak berdasar Undang-undang harus dikesampingkan sebagai alat bukti.

Dengan status sebagai tersangka membawa konsekuensi pula pada diberikan kewenangan kepada penegak hukum untuk melakukan berbagai upaya paksa, seperti penangkapan, penahanan, penyitaan, dan penggeledahan. Terhadap penggunaan upaya paksa yang tidak berdasarkan hukum, KUHAP melalui Pasal 77 telah memberikan kesempatan untuk menguji keabsahan penggunaan upaya paksa melalui permohonan pra-peradilan. Ketentuan Pasal 77 KUHAP membatasi diri untuk dapat menguji keabsahan penggunaan upaya paksa, dalam hal ini penangkapan dan penahanan tanpa menyertakan penggunaan penyitaan dan penggeledahan, namun di sisi lain KUHAP menampung hak untuk menguji keabsahan penghentian penyidikan dan penuntutan.

Dengan Putusan Mahkamah Konstitusi Nomor 21/PUUXII/2014 yang telah banyak menjadi dasar putusan pra-peradilan, penetapan tersangka dipandang sebagai salah satu bentuk upaya paksa, yang karenanya dapat diuji di pra-peradilan. Dengan perkembangan hukum mutakhir ini, maka telah diterima secara meluas dalam praktik hukum dan telah pula menjadi yurisprudensi bahwa penetapan tersangka sebagai salah satu bentuk upaya paksa selain penangkapan, penahanan, penyitaan, dan penggeledahan.

Dengan diterimanya penetapan tersangka sebagai bagian dari upaya paksa, maka proses penetapan tersangka juga harus dilakukan tidak ubahnya sebagaimana proses penangkapan, penahanan, penyitaan, dan penggeledahan, yang harus berdasarkan prinsip due process of law dan asas acusatoir. Dengan perubahan pemaknaan penetapan tersangka sebagai bagian dari upaya paksa, maka hak-hak warga negara telah harus dilindungi tidak sekadar sebelum ditetapkan menjadi terpidana atau pada saat bersatus sebagai tersangka, tetapi juga harus dilindungi sebelum dijadikan tersangka.

Dengan demikian, hak-hak yang melekat dalam diri tersangka 
karena demikian dekatnya untuk menjadi terpidana, juga perlu diberikan kepada mereka yang akan ditetapkan sebagai tersangka, atau disebut calon tersangka. Kualifikasi tersangka dengan terdakwa serta terpidana sangatlah mirip. Sebab, dalam praktik, bukan saja terpidana yang dapat dikenakan pembatasan atau perampasan hak asasi manusianya, melainkan juga tersangka dan terdakwa, yang terampas dan dibatasai hak asasinya, khususnya terkait dengan penahanan yang nyaris tidak berbeda dengan proses pemidanaan. Dalam praktiknya, bahkan seringkali para tahanan yang masih berstatus sebagai tersangka dikenakan penahanan yang ditempatkan di lembaga pemasyarakatan, yang sesungguhnya adalah tempat bagi mereka yang sudah dijatuhi pidana.

Penyimpangan penempatan tersangka di lembaga pemasyarakatan dan sebaliknya narapidana di rumah tahanan negara sudah berlangsung lama tanpa adanya perhatian serius dai negara untuk memperbaiki keadaan ini. Hampir tidak ada bedanya narapidana dengan tahanan dalam praktik, padahal secara normatif jelas sekali berbeda. Belum lagi stigma sosial yang membuat mereka terhukum sebelum dijatuhi hukuman.

Walaupun hak negara untuk menghukum merupakan hak istimewa yang hanya dimiliki oleh negara yang merupakan tuntutan kesulilaan sebagai kategorischeimperatife (dalam bahasa Indonesia lebih kurang dapat diartikan sebagai hukuman yang memang harus ada) sebagaimana dikemukakan Imanuel Kant, seseorang harus dipidana oleh hakim karena ia telah melakukan kejahatan. ${ }^{18}$ Dalam praktik, penyidik dan penuntut umum diberikan pula kewenangan menahan yang nyaris tidak berbeda dengan perampasan kemerdekaan yang dilakukan oleh hakim.

Kewenangan penyidik yang demikian itu perlu diimbangi dengan pemberian batasan-batasan tertentu dan ketentuan prosedur tindakan yang lebih menjamin dan melindungi hak tersangka dengan baik. Pembatasan kewenangan tersebut secara langsung berfungsi juga untuk melindungi kepentingan hak tersangka dari

18 Pontang Moerad, Pembentukan Hukum Melalui Putusan Pengadilan dalam Perkara Pidana (Bandung: Alumni, 2005), hlm. 73. 
kemungkinan penyalahgunaan wewenang yang dapat melanggar hak asasi tersangka. ${ }^{19}$

Tentu saja tidak semua hak tersangka dapat dan perlu diberikan kepada calon tersangka, karena memang tidak memungkinkan secara praktik. Namun pada umumnya hak tersangka seharusnya juga sudah didapatkan oleh seseorang yang dalam status calon tersangka, walaupun lembaga ini belum dikenal dalam KUHAP. Misal, hak untuk menghubungi penasehat hukum, hak untuk diberitahukan tentang dugaan tindak pidana yang dilakukan, hak untuk membela diri, hak untuk didengarkan keterangannya, dan hak untuk tidak dipaksa dan seterusnya. Pemberian hak ini sangatlah penting, karena meskipun belum ditetapkan sebagai tersangka, nasib para calon tersangka dalam praktiknya tidak ubahnya sama saja dengan nasib mereka yang sudah ditetapkan sebagai tersangka. Bahkan ada kalanya, nasib sebagai calon tersangka lebih mengenaskan karena sering juga status tersebut digantung atau tergantung dalam arti disengaja untuk kepentingan tertentu atau memang tidak disengaja karena terkendala pembuktian yang berlarut-larut.

Seseorang yang ditetapkan sebagai tersangka tidak diberikan batas waktu yang pasti kapan status tersangkanya itu berakhir. Hal ini membawa konsekuensi hukum tersendiri bagi tersangka. Walaupun secara yuridis belum ada kepastian dinyatakan bersalah, akan tetapi secara sosial orang tersebut sudah dianggap bersalah dan menanggung rasa malu di masyarakat. Bahkan dalam hal-hal tertentu, di satu sisi tersangka tidak bisa menggunakan hak-hak hukumnya secara maksimal, sehingga dinilai sangat merugikan dan tidak memberikan rasa keadilan. Pada sisi yang lain, tidak pastinya kapan status tersangka itu akan berakhir, sangat berpotensi terjadinya pelanggaran hak asasi manusia. ${ }^{20}$

Idealnya, penetapan tersangka ada batasnya. Dalam Undang-

19 Nazaruddin, Husni Djalil, dan M Nur Rasyid. "Perlindungan Hak Asasi Tersangka dalam Penyidikan Kepolisian (Studi Kasus di Polres Pidie)", Syiah Kuala Law Journal, 1, 2 (2017), hlm. 161.

20 Bahran, "Penetapan Tersangka Menurut Hukum Acara Pidanadalam Perspektif Hak Asasi Manusia”, Syariah: Jurnal Ilmu Hukum dan Pemikiran, 17, 2 (2017), hlm. 221. 
undang Nomor 18 Tahun 2013 tentang Pencegahan dan Perlindungan Perusakan Hutan, masa penyidikan dibaasi hanya 60 hari dan dapat diperpanjang menjadi 30 hari, sehingga total masa penyidikan adalah 90 hari. Hal ini telah sesuai dengan prinsip keadilan dan hak asasi manusia.

Berkaitan dengan hak-hak tersangka untuk didampingi, didengarkan keterangannya secara bebas, serta diperiksa dengan wajib hadir di muka sidang pengadilan, maka hak tersebut juga seharusnya diberikan kepada mereka yang masih berstatus sebagai calon tersangka sebelum ditetapkan sebagai tersangka. Hal itu disampaikan Eddy OS Hiariej dalam keterangannya di Mahkamah Konstitusi, bahwa dalam rangka mencegah kesewenang-wenangan penetapan seseorang sebagai tersangka ataupun penangkapan dan penahanan, maka setiap bukti permulaan haruslah dikonfrontasi antara satu dengan lainnya, termasuk pula dengan calon tersangka. Hal ini dibutuhkan untuk mencegah apa yang disebut dengan istilah unfair prejudice atau persangkaan yang tidak wajar. ${ }^{21}$ Tidak jarang di dalam praktik terjadi, seseorang secara tiba-tiba ditetapkan sebagai tersangka tanpa dipanggil terlebih dahulu, apalagi diberi kesempatan untuk membela dirinya atau mempersiapkan pembelaan.

Ketika negara dihadapkan dengan seorang yang diduga pelaku kejahatan, maka negara harus menempatkan dirinya sebagai orang tua dengan anak, bukan seperti musuh menghadapi musuh. Sebab, negara dapat dipandang sebagai asosiasi manusia yang hidup dan bekerja sama untuk mengejar beberapa tujuan bersama. Dapat dikatakan bahwa tujuan terakhir setiap negara ialah menciptakan kebahagiaan bagi rakyatnya (bonum publicum, common good, common wealth). ${ }^{22}$ Tujuan hukum pidana adalah untuk melindungikepentingan orang perseorangan atau hak asasi manusia dan melindungi kepentingan masyarakat dan negara dengan perimbangan yang serasi dari kejahatan/tindakan tercela di satu pihak dan dari tindakan

21 Pendapat Eddy OS Hiariej dalam dalam Putusan Mahkamah Konstititusi Nomor 21 / PUU-XII / 2014 hlm. 65.

22 Miriam Budiardjo, Dasar-Dasar Ilmu Politik (Jakarta: Gramedia Pustaka Utama, edisi revisi, cetakan kedua, 2020), hlm. 54. 
penguasa yang sewenang-wenang di lain pihak. Dengan demikian, yang dilindungi oleh hukum pidana bukan saja individu, tetapi juga negara, masyarakat, harta benda milik individu. ${ }^{23}$

Dalam proses pemeriksaan di pengadilan, seorang terdakwa sebelum menjadi terpidana wajib dihadirkan. Tujuannya adalah untuk mendengarkan semua proses mulai dari dakwaan, pemeriksaan saksi-saksi dan ahli, surat di mana setiap kali proses persidangan. Juga dipertanyakan pendapatnya, diberi kesempatan untuk bertanya dan membantah dakwaan, tuntutan, serta kesaksian orang-orang yang hadir dan diperiksa di muka pengadilan. Hal semacam ini seharusnya berlaku juga pada orang yang akan ditetapkan sebagai tersangka. Ia, calon tersangka, seharusnya diberi hak untuk menghadirkan saksi atau ahli, membantah atau mengingkari tuduhan, meminta pendampingan penasehat hukum, dikonfrontasi dengan para pelapor atau saksi dari pihak pelapor atau korban, walaupun tentu saja dengan kualitas yang berbeda dengan proses persidangan di pengadilan.

Dengan berdasar pemikiran dan kajian di atas, maka tidaklah berlebihan dan memang sepatutnya Mahkamah Konstitusi mewajibkan adanya pemeriksaan calon tersangka sebelum seseorang ditetapkan sebagai tersangka. Putusan Mahkamah Konstitusi terkait dengan kewajiban pemeriksaan calon tersangka sejalan dengan Putusan Mahkamah Konstitusi lainnya yaitu Nomor 130/PUUXIII/2015, yang amar putusannya menyatakan penyidik wajib memberitahukan dan menyerahkan surat perintah dimulainya penyidikan kepada penuntut umum, terlapor, dan korban/pelapor dalam waktu paling lambat tujuh hari setelah dikeluarkannya surat perintah penyidikan. Putusan Mahkamah Konstitusi yang disebut terakhir ini mengundang kesulitan yang serius bagi penyidik karena ada kekhawatiran terlapor atau calon tersangka melarikan diri begitu disampaikan surat pemberitahuan dimulainya penyidikan (SPDP). Namun Mahkamah Konstitusi berpandangan bahwa SPDP memang harus diberikan dalam kurun waktu tujuh hari dengan alasan memberi kesempatan terlapor (calon tersangka) mempersiapkan

23 Muladi, Kapita Selekta Sistem Peradilan Pidana (Semarang: Badan Penerbit Universitas Diponegoro, 1995), hlm. 37. 
pembelaan diri.

Dengan adanya dua putusan Mahkamah Konstitusi tersebut, jelas kiranya bahwa secara prinsip Mahkamah Konstitusi selaku the guardian of constitution memandang jaminan terhadap hak asasi manusia perlu diberikan dengan adanya kesempatan membela diri dan mempersiapkan pembelaan diri sejak awal, yaitu sejak seseorang belum ditetapkan sebagai tersangka (terlapor atau calon tersangka). Dengan dua putusan tersebut, proses penegakan hukum yang mengabaikan kewajiban memberikan SPDP di atas tujuh hari dan penetapan tersangka sebelum dilakukan pemeriksaan sebagai calon tersangka harus dinyatakan sebagai penyidikan yang tidak sah.

Adanya putusan pra-peradilan yang membatalkan penetapan tersangka seharusnya tidak dimaknai sebagai penghukuman bagi penyidik, karena pra-peradilan hanya memeriksa tentang keabsahan proses penyidikan apakah telah sesuai dengan prinsip due process of law, asas-asas sehingga tidak merampas hak asasi manusia. Putusan praperadilan sebagaimana disebutkan dalam Perma Nomor 4 Tahun 2016 tidaklah menggugurkan kewenangan penyidik untuk menetapkan yang bersangkutan sebagai tersangka lagi setelah memenuhi paling sedikit dua alat bukti baru yang sah, yang berbeda dengan alat bukti sebelumnya yang berkaitan dengan pokok perkara.

Berdasarkan uraian-uraian di atas, pemeriksaan calon tersangka sebelum penetapan tersangka memiliki relevansi apabila ditelaah dari perspektif keberlakuan hukum secara filosofis, yuridis, sosiologis. Pertama, hukum akan dikatakan berlaku secara filosofis jika sejalan dengan jiwa bangsa dan prinsip moral yang universal. ${ }^{24}$ Dalam konteks Indonesia, jiwa bangsa ini adalah Pancasila, ${ }^{25}$ yang salah

24 Barda Nawawi Arief misalnya, mengatakan hukum pidana haruslah berlandaskan pada moralitas umum, yaitu nilai keadilan, kebenaran, kejujuran, kepercayaan dan kasih sayang antar sesama. Barda Nawawi Arief, Beberapa Aspek Pengembangan Ilmu Hukum Pidana: Pidato Pengukuhan Guru Besar Ilmu Hukum Pidana Universitas Diponegoro (Semarang: Penerbit Pustaka Magister, 2011), hlm. 41.

25 M. Zulfa Aulia, "Friedrich Carl von Savigny tentang Hukum: Hukum sebagai Manifestasi Jiwa Bangsa”, Undang: Jurnal Hukum, 3, 1 (2020), hlm. 227-228. 
satu silanya adalah Kemanusiaan yang Adil dan Beradab. Hak untuk didengarkan dan diberi kesempatan membela diri seluas-seluasnya adalah hak universal dan hak dasar yang harus dijunjung tinggi. Siapapun orangnya harus diberikan kesempatan membela dirinya dan didengarkan keterangannya.

Pendekatan filsafat bertolak dari tiga hal, yaitu ontologi, epistimologi dan aksiologi. Dari perspektif ontologi, pemberian kesempatan pemeriksaan calon tersangka adalah pemberian kesempatan membela diri untuk tidak dituduh secara melawan hukum dan melampaui kewenangan. Secara espitimologis, lembaga pemeriksaan calon tersangka telah diperkenalkan dan dimungkinkan oleh Mahkamah Konstitusi. Secara askiologis, lembaga baru ini dimaksudkan untuk melindungi hak-hak tersangka.

Menurut Siswanto Sunarso, Pancasila dan UUD 1945 dapat disebut sebagai The Indonesian Bill of Human Right. Memahami hak asasi manusia dalam konteks sosiokultural bangsa akan menyadarkan bahwa hak-hak asasi manusia harus dilaksanakan dengan selalu menghormati hak-hak orang lain, ketertiban umum, keamanan nasional, asas-asas demokrasi Pancasila, moralitas masyarakat dan kesejahteraan umum. ${ }^{26}$ Dalam perspektif hak asasi manusia Universal, pemberian kesempatan calon tersangka membela dirinya sendiri sejalan dengan asas "fair trial" sebagaimana diatur dalam Optional Protocol to the International Covenant on Civil and Political Right (ICCPR) 1966, yaitu harus dijamin terselenggaranya peradilan yang jujur terhadap semua orang yang dituduh melakukan tindak pidana. Landasan utama fair trial adalah Artikel 10 dan 11 Universal Declaration of Human Right (UDHR) dan Artikel 14 dan 15 ICCPR yang menegaskan eksistensi hak seseorang atas "a fair and public hearing by a competent, independent and impartial tribunal established by law." ${ }^{27}$

26 Siswanto Sunarso, Filsafat Hukum Pidana: Konsep, Dimensi dan Aplikasi (Jakarta: RajaGrafindo Persada, 2015), hlm. 279.

27 Muladi, "HAM dalam Perspektif Sistem Peradilan Pidana", dalam Hak Asasi Manusia: Hakekat, Konsep, dan Implikasinya dalam Perspektif Hukum dan Masyarakat, ed. Muladi (Bandung: Refika Aditama, 2009), hlm. 106. 
Kedua, hukum akan dikatakan berlaku dan memiliki landasan yuridis apabila kaidah hukum memiliki landasan hukum yang hirarkis. Dalam kaitan dengan pemeriksaan calon tersangka, saat ini sudah memiliki landasan hukumnya, yaitu putusan Mahkamah Konstitusi, meski juga harus dikatakan tidak dalam bentuk amar putusan melainkan dibunyikan dalam pertimbangannya. Oleh karena putusan Mahkamah Konstitusi bersifat final dan mengikat, maka sepatutnya isi putusan dipatuhi terlebih oleh penegak hukum. Dalam KUHAP sendiri, berdasarkan ketentan Pasal 114, dinyatakan bahwa sebelum dilakukan pemeriksaan kepada orang yang disangka melakukan tindak pidana, penyidik wajib memberitahukan kepadanya tentang hak mendapatkan bantuan hukum, khususnya terhadap tindak pidana yang ancaman pidananya lebih dari lima tahun. Menurut Syarifudin Petanasse, arti penting diberikannya tersangka hak mendapat bantuan hukum sebelum diperiksa adalah berkaitan dengan adanya kemungkinan ia ditahan setelah menjadi tersangka. ${ }^{28}$

Ketiga, dilihat dari perspektif sosiologis, suatu kaedah hukum dianggap berlaku jika memiliki dasar keberlakuan secara sosiologis. Secara sosiologis, masyarakat Indonesia sangat menghormati hakhak orang untuk didengarkan sebelum dinyatakan bersalah. Tradisi peradilan adat di Indonesia, yang menempatkan kedua belah pihak secara setara dan sejajar, dapat dibaca sebagai penerimaan atau kesesuaiannya secara sosiologis. Dengan demikian, pemberian kesempatan pemeriksaan calon tersangka sebelum ditetapkan sebagai tersangka sudah sejalan dengan prinsip kesetaraan para pihak dalam masyarakat Indonesia. Berbagai etnik di Indonesia bahkan jauh lebih maju dengan memperkenalkan prinsip yang dikenal di dunia modern sebagai restorative justice, di mana peran korban ikut diperhitungkan dalam menentukan hukuman apa yang patut dijatuhkan kepada pelaku. Pendekatan masyarakat bukan pada pemidanaan, akan tetapi pada sistem restorasi yang menekankan prinsip sama-sama menang.

28 Syarifuddin Petanasse, Hukum Acara Pidana (Palembang: Penerbit Universitas Sriwijaya, 1997), hlm. 115. 


\section{Kesimpulan}

Penetapan seseorang sebagai tersangka adalah bagian dari upaya paksa dan bahkan hampir setara dengan penetapan seseorang sebagai terpidana, disebabkan berbagai pembatasan yang dapat diterapkan secara sama. Sebelum seseorang terdakwa divonis bersalah dan menjadi terpidana, hak-haknya untuk diperiksa dengan kehadirannya di setiap persidangan adalah wajib dan merupakan bagian dari hak asasi manusia yang bersifat universal. Dengan fakta hukum tersebut, maka pemeriksaan calon tersangka sebelum seseorang ditetapkan sebagai tersangka amat penting dan seharusnya dilakukan sebagai kewajiban penyidik sesuai dengan prinsip due process of law, asas acusatoir, prinsip universal hak asasi manusia, dan sejalan dengan Putusan Mahkamah Konstitusi yang menekankan arti penting kesempatan pembelaan diri terlapor atau calon tersangka sebelum ia ditetapkan sebagai tersangka.

\section{Daftar Pustaka}

\section{Artikel dan Buku}

Arief, Barda Nawawi. Beberapa Aspek Pengembangan Ilmu Hukum Pidana: Pidato Pengukuhan Guru Besar Ilmu Hukum Pidana Universitas Diponegoro. Semarang: Penerbit Pustaka Magister, 2011.

Aulia, M. Zulfa. "Friedrich Carl von Savigny tentang Hukum: Hukum sebagai Manifestasi Jiwa Bangsa”. Undang: Jurnal Hukum, 3, 1 (2020): 201-236. DOI: 10.22437/ujh.3.1.201-236.

Bahran. "Penetapan Tersangka Menurut Hukum Acara Pidana dalam Perspektif Hak Asasi Manusia”. Syariah: Jurnal Ilmu Hukum dan Pemikiran, 17, 2 (2017): 220-239. DOI: 10.18592/ sy.v17i2.1972.

Budiardjo, Miriam. Dasar-Dasar Ilmu Politik. Jakarta: Gramedia Pustaka Utama, edisi revisi, cetakan kedua, 2010.

Hamzah, Andi dan RM Surachman. Pre Trial Justice Discretionary Justice dalam KUHAP Berbagai Negara. Jakarta: Sinar Grafika, 2015. 
Harahap, M. Yahya. Pembahasan Permasalahan dan Penerapan KUHAP: Penyidikan dan Penuntutan. Jakarta: Sinar Grafika, 2002.

Heryansyah, Despan dan Harry Setya Nugraha. "Relevansi Putusan Uji Materi oleh Mahkamah Konstitusi terhadap Sistem Checks and Balances dalam Pembentukan Undang-Undang”. Undang: Jurnal Hukum, 2, 2 (2019): 353-379. DOI: 10.22437/ ujh.2.2.353-379.

Ihsani, Ardli Nuur. "Urgensi Perluasan Objek Praperadilan dalam Tindak Pidana Korupsi Ditinjau dari Perspektif Perlindungan Hak Asasi Tersangka”. Legal Standing: Jurnal Ilmu Hukum, 1, 2 (2017): 66-85. DOI :10.24269/1s.v1i2.772.

Marbun, Rocky. Telaah Kritis Filosofis Praktik Peradilan Pidana: Membongkar Oposisi Biner antara Kekuasaan dan Kewenangan. Yogyakarta: Arti Bumi Intaran, 2019.

Moerad, Pontang. Pembentukan Hukum Melalui Putusan Pengadilan dalam Perkara Pidana. Bandung: Alumni, 2005.

Muladi. Kapita Selekta Sistem Peradilan Pidana. Semarang: Badan Penerbit Universitas Diponegoro, 1995.

Muladi. "HAM dalam Perspektif Sistem Peradilan Pidana”. Dalam Hak Asasi Manusia: Hakekat, Konsep, dan Implikasinya dalam Perspektif Hukum dan Masyarakat, diedit oleh Muladi, 99110. Bandung: Refika Aditama, 2009.

Nazaruddin, Husni Djalil, dan M Nur Rasyid. "Perlindungan Hak Asasi Tersangka dalam Penyidikan Kepolisian (Studi Kasus di Polres Pidie)". Syiah Kuala Law Journal, 1, 2 (2017): 145162. DOI: $10.24815 /$ sklj.v1i2.8478.

Petanasse, Syarifuddin. Hukum Acara Pidana. Palembang: Penerbit Universitas Sriwijaya, 1997.

Rafsanjani, Muhammad Sayed, Iskandar A. Gani, dan Mohd. Din. “Terhadap Pemeriksaan Tersangka yang Dilakukan Penyidik Kaitannya dengan Kode Etik Kepolisian Negara Republik Indonesia”. Jurnal Ilmu Hukum, 3, 3 (2015): 59-67.

Raharjo, Agus dan Angkasa. "Perlindungan Hukum terhadap Tersangka dalam Penyidikan dari Kekerasan Penyidik di Kepolisian Resort Banyumas”. Mimbar Hukum, 23, 1 (2011): 
77-97. DOI: 10.22146/jmh.16202.

Rukmini, Mien. Perlindungan HAM melalui Asas Praduga tak Bersalah dan Asas Persamaan Kedudukan dalam Hukum pada Sistem Peradilan Pidana Indonesia. Bandung: Alumni, 2007.

Rukmini, Mien. Aspek Hukum Pidana dan Kriminologi: Sebuah Bunga Rampai. Bandung: Alumni, 2009.

Sunarso, Siswanto. Filsafat Hukum Pidana: Konsep, Dimensi dan Aplikasi. Jakarta : RajaGrafindo Persada, 2015.

TriBawono,Bambang. “Tinjauan YuridisHak-HakTersangkadalamPemeriksaanPendahuluan”. Jurnal Hukum, 26, 2(2011):550-570. DOI: $10.26532 /$ jh.v26i2.209.

\section{Putusan Hukum}

Republik Indonesia, Mahkamah Konstitusi. Putusan Nomor 21/ PUU-XII/2014, perkara pengujian Undang-Undang Nomor 8 Tahun 1981 tentang Hukum Acara Pidana terhadap Undang-Undang Dasar Negara Republik Indonesia Tahun 1945.

Republik Indonesia, Mahkamah Konstitusi. Putusan Nomor Nomor 130/PUU-XIII/2015, perkara Pengujian Undang-Undang Nomor 8 Tahun 1981 tentang Hukum Acara Pidana terhadap Undang-Undang Dasar Negara Republik Indonesia Tahun 1945. 